COMMENT

https://doi.org/10.1057/s41599-019-0312-z

\title{
What guns meant in eighteenth-century Britain
}

Priya Satia ${ }^{1}$

\begin{abstract}
This article briefly summarizes the place of guns in British society and culture in the long eighteenth century. My approach is that of a historical anthropologist, examining the meaning of guns from the way they were used and depicted. I examine the way guns were used and understood in civilian and military realms, especially their meaning and role in the expansion of the British Empire. Finally, the essay discusses whether and how this history should influence our understanding of the Second Amendment, which was written in the eighteenth century. It concludes that history substantiates both sides of the current debate about gun use in America and that we must therefore turn to other ethical systems of judgment to resolve that debate.
\end{abstract}

${ }^{1}$ Stanford University, Stanford, USA. Correspondence and requests for materials should be addressed to P.S. (email: psatia@stanford.edu) 


\section{Introduction}

oday, many Americans see guns as a symbol of freedom from tyranny. They credit the Second Amendment, written in 1791, for having saved the newly freed United States from the fate of Britain's other colonies: places like India whose tight gun control laws originated in British efforts to keep arms out of the hands of anticolonial revolutionaries. But many more Americans calling for tighter gun control today see guns themselves as tyrannical: the imperial rulers' instruments of conquest, enslavement, and genocide, which now terrorize a generation of American school children.

Both narratives look to history for validation about the true meaning of guns in America. While social scientists gather data about the effects of guns today, much of the debate about whether and how to regulate gun ownership is fought out on the terrain of history: What did the Second Amendment mean? Is there a tradition of gun control in America? Have Americans always been well-armed and liberally-armed? The implication is that the proper role of guns in American life today depends on their historical role: the side with the more accurate historical narrative should carry the day. If guns have historically been the bedrock of American liberty, so should they continue to be; if they have not, they may not become so now. Meanwhile, the dispute itself drives panic gun purchases by a pro-gun community fearing imminent controls.

In fact, history offers substance to both narratives about "what guns mean"-the focus of this Palgrave collection (Metzl, 2019). To get at this varied cultural inheritance, I sketch here guns' role in the era of the Second Amendment, particularly in British colonial expansion and the rise of private property-and how their meaning evolved afterwards. Deepening historical knowledge this way may enable more empathetic discourse; but, in the end, I argue, it cannot resolve our debate about gun control. Too many urgent present-day realities are at stake in that debate, and we are accountable in and to our present. It is time to turn away from history to other systems of ethical judgment. It matters less whose side history is on than who is on the right side of history.

\section{Guns in eighteenth-century Britain}

The Glorious Revolution of 1689 established a constitutional monarchy in Britain under William and Mary. Not everyone was happy; Jacobites sought the return of the ousted Catholic Stuart king and were recognized as an existential threat to the new regime. Guns' warlike uses were clear enough to prompt tight regulation of their possession in this insecure time. Gun ownership was a prerogative of the upper classes and the state (Satia, 2018a, pp. 220-225).

But guns had other uses and meanings, too, arising from their particular qualities in that time. Eighteenth-century guns were unlike guns today. They were heavy and unwieldy, prone to rust and rot, and slow and unreliable in their functioning. A mass shooting with an eighteenth-century gun was inconceivable. Nor was a gun useful in a moment of fury; it took too long to use and was too potentially ineffectual in the heat of the moment. The very nature of the mechanical, slow process for loading and triggering made it a weapon of cool threat rather than hotblooded violence. As a result, before the 1790s, guns were not used in crimes of passion; angry eighteenth-century people reached for whatever blunt instrument was near at hand, or settled for bare hands and feet. Rioters did not use guns, either (Satia, 2018a, pp. 225-247). ${ }^{1}$

Instead, in eighteenth-century Britain, guns made new kinds of violence related to property possible. In everyday life, they were used almost exclusively in situations of smuggling, robbery, poaching, and protection of property against such acts. In such scenarios they were instruments of intimidation, part of an emerging culture of politeness in which even the highwayman was known as a "gentleman of the road." They were for waving in the face of strangers against whom one had no personal complaint but who threatened one's claim to private property.

Most property violations were new sorts of crimes. Private property was an aberration in a long history of communal landholding in England and around the world, and guns were critical to its emergence in Britain-and its violent exportation abroad. With the revolution of 1689 , the purpose of government was understood as guaranteeing property. Legal terror, in the shape of the infamous "Bloody Code" made property violations like petty theft, food riot, forgery, and resistance of enclosure capital offenses. Privately owned guns were integral to this cheap solution to preservation of property. The state was not yet institutionally coherent enough to have a monopoly on violence; it depended on partnership with private power. A regular police force was anathema to a Francophobic gentry traumatized by memories of the Stuarts; legal terror and the gun at the property holder's bedside were acceptable substitutes. For, as a popular Birmingham historian explained, "No property will protect itself" (Hutton, 1835, p. 413). Justice Christian Ely likewise counseled increasing "the terror of house-breakers," with the death sentence and a brace of pistols at his bedside (cited in Hay, 1975, p. 18). In an influential pamphlet, Colonel George Hanger insisted that there was "no better defence for a house, than a double-gun, nor against robbers on the road" (Hanger, 1814, pp. 149-150). In 1790, the Birmingham newspaper advised "persons living in the country" to acquire "sufficient...fire arms" to forestall intrusion (Aris's Birmingham Gazette, 25 January 1790, p. 3). If property is the power to exclude others from taking or using certain things, the gun was the handheld instrument that made it effective (along with the law).

Guns embodied sovereign power. A threat against property was understood as a threat against the post-1689 regime that established its rise. Today's gun advocates may invoke hunting as an apolitical use of guns, but it is rooted in a deeply political contest over access to land. Poachers, highwaymen, and smugglers carried the taint of Jacobitism. Their use of firearms to that end symbolized a political challenge to the state's legitimacy. The gun was a miniaturized cannon, instantly militarizing any setting, transforming it into a battlefield over 1689. In a time of inchoate state policing institutions, distribution of miniature cannon among the propertied classes militarized the ostensibly private sector to defend the private property that was the post-1689 regime's raison d'etre. The law sanctioned civilian use of guns to defend property. Gamekeepers were licensed to kill poachers. Gun fatalities resulting from the defense of property typically ended in acquittal (Satia, 2018a, p. 246).

The tension and fear of physical conflict is almost entirely debilitating at close range without sufficient emotional motivation (Collins, 2008, pp. 58-59). The firearm could be wielded from afar, making less emotionally motivated violence possible. Its impact was understood as the unpredictable outcome of an impersonal and highly unpredictable mechanical process that need not impinge on the user's conscience in the way that a purposeful, emotionally motivated act of violence might. The presumed ease of perpetrating this mechanical, dispassionate violence without intense emotional investment and without incurring cost to the conscience was theoretically what made waving a gun effective in inhibiting defiance. That was the source of its power as an instrument of terror in eighteenth-century England. The sword expressed the personal, aristocratic quality of chivalry; the gun, the impersonal, bourgeois quality of private property. ${ }^{2}$ Operating outside the domain of the passions, firearms 
helped produce the eighteenth-century masculine ideal of the bounded self possessing bounded property.

Military use of guns was also related to defense of property. Troops wielded muskets against rioters threatening property and property-owners. The Riot Act of 1715 indemnified civilians for shooting rioters in aid of troops. Britain's wars were understood as the defense of property on a national scale; the French enemy threatened the post-1689 regime and the property relations it ushered in. In battle, too, guns were used and understood as instruments of terror. They were not aimed; soldiers loaded and fired in unison. It was through their "noise...smoke" and threat of "invisible death" that they revolutionized war, according to the moral philosopher Adam Smith (1776; 1994, pp. 755-756). Firing struck the enemy at random, and often it was the bayonet charge up close that decided the outcome.

\section{Guns in the eighteenth-century British Empire}

British imperial expansion in this period depended critically on guns. Guns were objects of the trade that drove expansion and facilitators of that trade, including, especially, the slave trade (Satia, 2018a, pp. 261-299). In the advertisement below from a Bristol gunmaker, a generic "native" has put down his bow and arrow and taken up a musket that puts him on par with the property-owning Briton. The ship behind him symbolizes the spread of civilization, and it is a civilization based on property, embodied by the Englishman with his hound, manor, and fowling piece on the left. The armed native is not a frightening figurethough he will become one by the next century (Fig. 1).

This supposed "civilizing" function routinely trumped awareness of guns' violent function. Colonial officials periodically expressed the fear that by spreading arms among Native Americans or South Asians, the British were arming their enemies against themselves. But such concerns were inevitably assuaged by the assurance that abstaining from such sales would only send these customers into the arms of other suppliers. The British would thereby forfeit profit, prestige, and diplomatic influence to their rivals, the Dutch and the French. Worse, they would sabotage their struggle to suppress indigenous arms-manufacturing, which posed a military and economic threat to British power. They knew that arms-manufacture was critical in driving industrial revolution in Britain just then (Satia, 2018b). Guns proliferated in millions around the world thanks to this logic.

In imperial expansion, guns were not only commercial and diplomatic currency but literally money, valued for their metallic content and their symbolic association with sovereign power (Satia, 2018a, pp. 191-218). Most importantly, in the hands of British settlers, explorers, and soldiers, guns facilitated colonialism by violently enabling expropriation, extraction, and subjugation. In the South Pacific, their use against aboriginal populations was exterminatory (Satia, 2018a, pp. 263-267). Guns enabled Britons to fulfill their historic project of spreading the reign of property around the world in the name of "civilization." But their complex social life, underwriting pacific images like the one above, helped conceal that reality. Adam Smith was confident that though it "at first sight appears to be so pernicious," giving an advantage to an "opulent and civilized over a poor and barbarous nation," the invention of firearms favored both "the permanency and...the extension of civilization" (1776; 1994, pp. 765, pp. 675-676).

Eighteenth-century American gun culture overlapped with this British culture. Settlers headed to the colonies armed, and gun sales were integral to the European contest for the allegiance of Native nations. Gun ownership rates were higher in the colonies than in Britain, but most colonists did not have military-grade arms (Sweeney, 2013). They, too, used guns in conflicts around property-including the larger scale struggle for native lands. Guns were also used for pest control and hunting. They were part of the culture of the frontier-carried by exploring parties as weapons (ostensibly for defense, but often used offensively), but also fired to signal for help or announce a welcome or triumph (Satia, 2018a, pp. 267-283). Europeans sold and gifted arms to Native American powers, and used them as currency. The Second Amendment was written in 1791 when guns were understood and used in these ways.

Today guns fit differently in American culture: American civilians do own military-style firearms and use guns in crimes of passion, especially domestic violence. We use them in mass shootings. The most formidable firearm in 1791, a

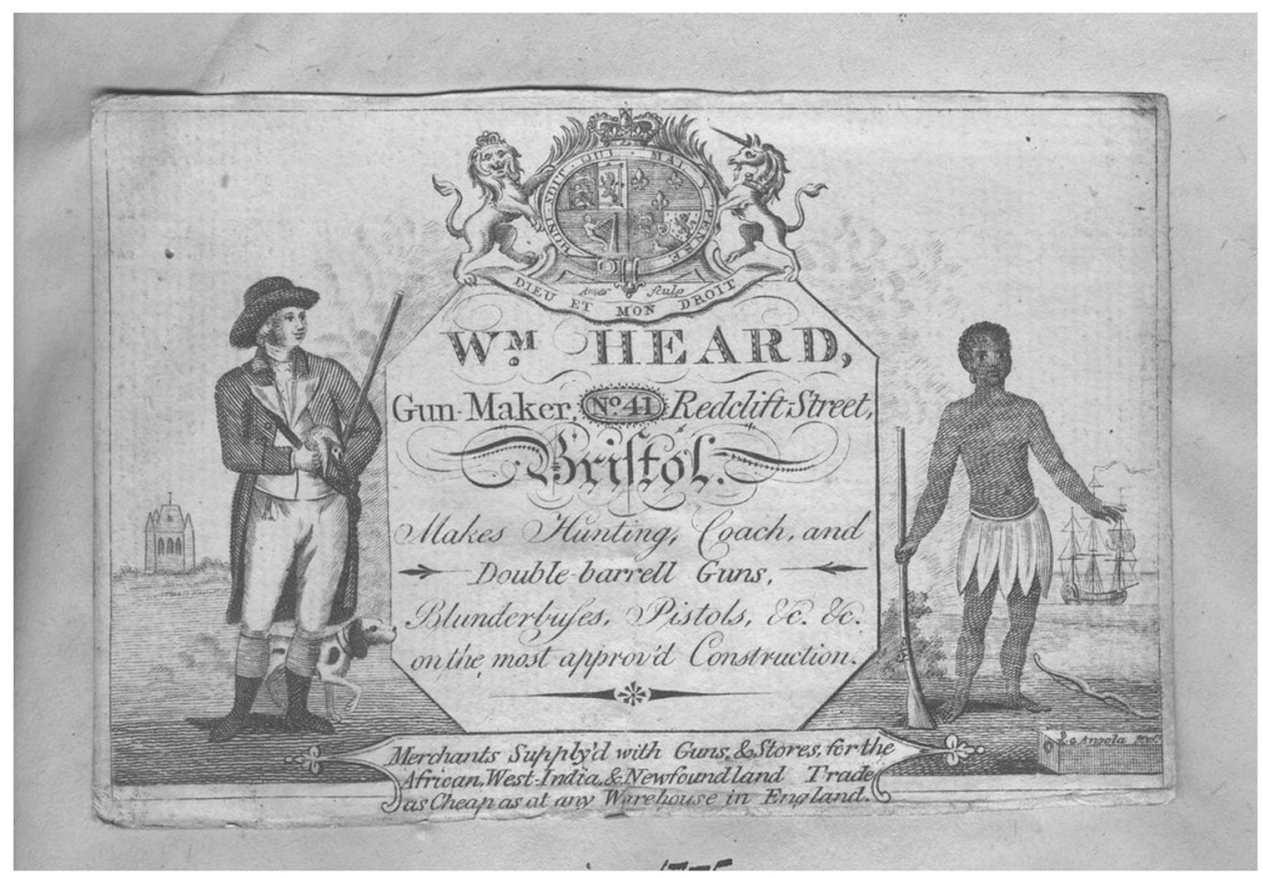

Fig. 1 Advertisement by William Heard, gun-maker of Bristol. Copyright Bristol Reference Library. Permission granted to author by email on June 9, 2019 
muzzle-loading single-shot firearm, is incomparable in use and effect to the semi-automatic weapons many Americans seek to regulate today.

The question then is: Does the Second Amendment's reference to "Arms" in the phrase "the right of the people to keep and bear Arms" refer to firearms? All firearms? even if they have radically different uses and meaning from those that existed in 1791? Can the Second Amendment be held to protect modern arms even if their basic function is fundamentally different? Even in 1791, it was about ensuring the availability of particular kinds of arms, providing reassurance that if the federal government neglected to arm the militia, state governments might do so (Sweeney and Cornell, 2013). The concern was to secure military-grade muskets for state militias who might only have access to their fowlers at home-national defense, not self-defense. The amendment thus hung on an awareness of the material differences between different sorts of guns. Must we not, too, then be discriminating in talking about the appropriate uses of different types of firearms?

\section{How the meaning of guns changed from the late eighteenth century}

In Britain, use and regulation of guns changed dramatically soon after 1791. War against revolutionary and Napoleonic France began in 1793, lasting until 1815. This was a period of mass arming on an unprecedented scale. Training in arms for the state became "the most common collective working class experience" (Colley, 1994, p. 312). Long exposure to and practice in using guns to kill impersonally shaped an entire generation. Guns began to appear in reports of untimely civilian death with startling frequency-often perpetrated by former soldiers (Satia, 2018a, pp. 250-255). They were implicated in new kinds of deliberate homicides unrelated to either property or passions. For example, in Gloucester in 1802, a fifteen-year-old discharged soldier waved his musket at people "threatening to fire, to intimidate them." Then on Bristol Bridge, without giving any notice, he "wantonly drew the trigger" and killed a man (HVD Gloucester, 27 September 1802). These wars produced a generation capable of a new kind of impersonal and casual violence with guns unrelated to property. Rioters took up firearms, too (Satia, 2018a, p. 252). Though most murders went on by strangling and beating as before, guns had a role that they had not possessed in 1791. After a period in which their use was confined to the impersonal defense or seizure of property, they found a role in a new kind of impersonal violence against the person. Mass exposure to military gun violence produced new kinds of civilian gun violence. Just then, the movement to abolish the slave trade also depicted guns negatively, highlighting their destructive role in the trade and on plantations.

Against this backdrop, culture shifted again. With the end of the wars in 1815, demobilization, high food prices, and a postwar industrial downturn triggered radical protest, and the government reverted to tight controls on arms possession (Satia, 2018a, p. 255). It also established its own policing units, and Victorian citizenry surrendered to these state bodies much of their predecessors' autonomy in dealing with thieves. Guns in the hands of property owners disappeared. Highwaymen disappeared. The Vagrancy Act of 1824 policed armed men roaming the country, followed by a spate of legislation against the use of firearms for poaching $(1828,1830,1844,1862)$. In the twentieth century, regulations on gun ownership became tighter (Satia, 2018a, pp. 380-410).

Certainly, this is a story of triumphant class repression, oppressive government discipline. Likewise, increasingly strict control of firearms possession in British colonies-in India, South Africa, and elsewhere-secured British colonial rule. With the rise of powerful anticolonial movements, the arms the British had so liberally spread around the world appeared dangerous in a new way. Tight controls on gun ownership in India, New Zealand, and South Africa were precisely the "tyranny" that Americans might feel the Second Amendment preserves them from. After the First World War, especially, the British worked to ensure against the dangerous reality that "Any fool...can shoot a viceroy" (Mark Sykes, cited in Ball, 2012, p. 821).

But the analogy is not so simple. In the colonies, gun control was racialized, designed to keep guns out of the hands of nonwhites. Arguably, the Second Amendment was also about arming militias to keep a nonwhite enslaved population in its place and expropriate non-white indigenous people. In other words, disarmament in British colonies and armament in the United States both served colonial purposes, practically speaking. Diplomatic efforts to control international gun sales after World War One failed because the United States wanted no part in protecting European empires-but also because it did not want to harm its own arms exports to Latin America in the interest of American "security" (Stone, 2000, pp. 219-221). Context is everything.

In the 1950s, under the leadership of Martin Luther King Jr., the civil rights' movement took the American struggle against tyranny in a direction antithetical to libertarian interpretations of the Second Amendment: Americans were not going to defend against tyranny with guns but through collective noncooperation. But this movement did not function in isolation. Alongside, other revolutionary movements pushed for change with different tactics. The Black Panther Party asserted the Second Amendment rights of African-Americans facing routine police brutality. The 1967 NRA-supported California gun control law, the Mulford Act, strove to disarm such revolutionaries. By calling for gun control today, are we replicating that oppression? ${ }^{3}$ Or, are we emulating the 1968 Gun Control Act, which sought to prevent terrorizing uses of guns after King himself was fatally shot? Guns and gun control cut both ways in our past.

\section{Getting past the history of guns}

The truth is that history provides no way out of today's impasse between gun rights and gun reform. Even if scholars are right that the Second Amendment was not about individual defense, the 2008 Supreme Court Heller decision claiming that it was has now governed American thought, practice, and culture for more than a decade. This view is founded on a mythology about American gun culture propagated by gun manufacturers' and their lobbyists to preserve access to the American civilian market. Strict guncontrol regulations in Britain after mass shootings in 1987 and 1996 were eased by the absence of a powerful gun-makers' lobby there by then. The British government had come to rely on manufacturers abroad for its needs. Now governments around the world depend on the survival of American gun manufacturers, which in turn depends on American civilian buyers-the single biggest market for firearms sales today (Satia, 2018c). Unfettered access to this market has become crucial to manufacturers as controls have tightened elsewhere. This practical reality of governments', gun manufacturers', and related industries' interest in gun proliferation is the invisible context of our debate about the Second Amendment and whether guns are essentially liberating or tyrannizing, based on constitutional and cultural history.

And this context is itself the product of history made by guns. Guns were essential to the eighteenth-century emergence of the idea of that the vicissitudes of time were in fact the working out of "history" in terms of progress, as in Adam Smith's words above about their role in the spread of civilization. They figured centrally in the industrialism, empires, and nation-states that modern history took as the vehicles of such progress. Historical thinking is a 
cultural and intellectual inheritance of a world made with guns (Satia (MS)). Guns shaped the emergence of the universal object of modern history: the emotionally regulated property-owning self.

Given this entanglement, history might not be the right lens through which to determine the appropriate role of guns in America today. Distinguishing history from myth is always important, especially with respect to guns in America. Acknowledging the mixed historical record of guns in America can promote more respectful debate. But how we act must be governed by other ethical imperatives than simply hewing to a past that we have repurposed to our contemporary needs. History is a red herring in this debate. We are ethically accountable to our present, as the founding fathers were in 1791 .

Anthropology offers an alternative approach, and this collection of essays exploring the symbolic meanings of guns, takes us in that direction. It attempts to demonstrate that guns mean different things to different people. Still, it remains couched in historical terms since those meanings are historically derived.

Fortunately, the past itself is littered with examples of ways to escape such ethical dilemmas. Both sides of the gun control debate are ultimately concerned with freedom from tyranny; that is their common ground. And we have inherited a vast global history of intellectual and practical experiments in fighting tyranny, which has shaped American history, too. Martin Luther King's campaign took inspiration from the anticolonial thinker and activist Mohandas Gandhi, whose critique of violence was at once a critique of history as a guide to ethical action. He perceived that the countless moments in which the force of love prevails leave no mark in a historical record that is, essentially, an account of progress exacted through conflict (Gandhi, 1910, chap. 17). This, he felt, was the wisdom of the proverb, "Happy is the nation that has no history." He condemned both the violence of empire and violent efforts to end it for the way they replicated the tyranny of the oppressor. Nonviolence offered the only real escape from tyranny.

Gandhi was shot, in 1948. We might conclude from his and King's violent ends that their effort to imagine change wrought nonviolently met with defeat, that history can, in fact, only be an account of violent change. But we might more constructively recover the ethical alternatives they offered to address our current impasse and the plague of mass shootings. If history does not conclusively support either gun proliferation or gun control in the United States, what other values might guide us in addressing our immediate problem of rampant gun violence? Instead of the sovereign property-owning self, governing emotions within the bounds of propriety, might we imagine the practice of nonviolence and non-violent protest as self-rule, as its own escape from tyranny?

Gandhi's point was that violence breeds violence. The postWorld War One risk of a fool shooting a viceroy was borne of colonial violence and massive world war. As in 1815, an entire British generation was traumatized by impersonal military violence. They too began using guns in riots at home, until the 1920 Firearms Act disarmed them. Today's mass shootings in America are likewise framed by the war on terror. Apart from trauma and bigotry fueled by that conflict, the very attraction of the assaultstyle weapons shooters favor lies in their image of combat-style American masculinity grafted on to the sovereign liberal subject invoking castle doctrine (Satia, 2018d). To break this cycle of violence and reaffirm authentic self-rule requires fearless nonviolence-regardless of what the Second Amendment entitles one to. It requires adopting a different morality from the one that enabled the history of empire and industrialism in which guns were so central.

For those concerned with guns' deep cultural significance to American identity, many objects and moments might function as their cultural surrogates. There are economic surrogates for guns, too; their manufacturers can make other things, as they have in the past. "Remington" is a brand associated with much more than firearms. In clinging to history as the ground for our debate about what guns mean, we are perpetuating history as a stalemated contest between oppressors and oppressed.

To appreciate the advantages of gun control in Britain and its former colonies today is not necessarily to endorse the class or colonial tyranny that produced those controls. Context is everything: in today's context of mass shootings, British firearms regulation represents a case of good governance worth emulating.

As technologies evolve, we habitually regulate their use. Cars did not exist in the eighteenth century; the Constitution can offer no guidance about them. So, we invented a body of traffic laws in the cause of public safety. As telephone technology has evolved from the device Alexander Graham Bell invented to today's iPhone, which fits into our lives in dramatically different ways, new regulations and social conventions emerge to govern its uses. Today's firearms are only nominally the same objects as the firearms available in 1791, and likewise require new regulations.

We have implicitly agreed that the Second Amendment does not apply to "arms" such as tanks, nuclear bombs, bazookas, and missiles-at least according to the Heller decision. This means we know that it is up to us to decide where we draw the line between arms to which the people have a right and arms to which they do not. At the turn of the nineteenth century, the rising use of guns in casual violence and the exposure of guns' role in slavery caused Britons to turn their back on the historical narrative about guns' civilizing effects, at least at home (abroad, the civilizing excuse remained lethally influential). Their consequent disappearance (at home) did not spell the end of protest against class tyranny, which found other modes of expression. In this time of mass shootings Americans too might turn their backs on guns' American history in favor of the other tactics for fighting tyranny that we have also made our own. We too might then make new history, in which guns mean something else.

Received: 10 June 2019 Accepted: 12 August 2019

Published online: 10 September 2019

\section{Notes}

1 On the rare instances in which a gun figured prominently in a crime of passion or riot, see Satia (2018a), p. 226, p. 234.

2 By the 1780s pistols were adapted to the aristocratic custom of dueling, making it easier for those unskilled at swordplay to participate and making this eminently choreographed form of violence more polite. Duelers were required to raise their weapons and fire in a single movement without pausing to aim. Parties took to firing into the air as a pragmatic and honorable way of terminating the conflict. Some fought with powder and no ball. Pistols did not make duels less deadly but allowed the custom to evolve with notions of gentlemanly honor (Banks 2010, pp. 126-127, p. 206, p. 208) A man killed in a pistol duel fell "victim to modern honour" (Aris's Birmingham Gazette, 26 June 1797, p. 3).

3 See also Miles, 2019.

\section{References}

Aris's Birmingham Gazette, 25 January 1790, p. 3.

Aris's Birmingham Gazette, 26 June 1797, p. 3.

Ball S (2012) Britain and the decline of the international control of small arms in the twentieth century. J Contemp Hist 47(4):812-837

Banks S (2010) A polite exchange of bullets: the duel and the English gentleman, 1750-1850. Boydell, Woodbridge, UK and Rochester, New York

Colley L (1994) Britons: forging the nation, 1707-1837. Yale University Press, New Haven

Collins R (2008) Violence: a micro-sociological theory. Princeton University Press, Princeton

Gandhi M (1910) Hind swaraj or Indian Home Rule. orig. Gujarati 1909. Navajivan, Ahmedabad 
Hanger G (1814) To all sportsmen, and particularly to farmers, and gamekeepers. In: Stockdale JJ (ed) Above thirty years' practice in horses and dogs. London

Hay D (1975) Property, authority and the criminal law, 17-63. In: Hay D, Thompson EP, Linebaugh P (eds) Albion's fatal tree: crime and society in eighteenth-century England. Pantheon, New York

Historical Violence Database (HVD) (1802) Ohio State University, Gloucester Inquests. https:/cjrc.osu.edu/research/interdisciplinary/hvd/europe/bristol-and-gloucester

Hutton W (1835) The history of Birmingham, 6th edn. G. Berger, London

Metzl J (2019, April 2) What guns mean: the symbolic lives of firearms. Pal Commun. https://www.nature.com/articles/s41599-019-0240-y

Miles T (2019, March 9) The black gun owner next door. New York Times. https:// www.nytimes.com/2019/03/09/opinion/sunday/gun-ownership-blacks.html

Satia P (2018a) Empire of guns: the violent making of the industrial revolution. Penguin, New York

Satia P (2018b, February 14) Guns and the British empire. Aeon. https://aeon.co/ essays/is-the-gun-the-basis-of-modern-anglo-civilisation

Satia P (2018c, April 10) The hidden link between mass shootings in the U.S. and the global economic history of the firearms industry. Time Magazine. http:// time.com/5231027/economic-history-gun-control/

Satia P (2018d, November 14) Mass shootings-When the 'War on Terror' comes home. San Francisco Chronicle. https:/www.sfchronicle.com/opinion/openforum/ article/Mass-shootings-are-shaped-by-the-arms-industry-13393403.php

Satia P (MS) Time's monster: history, conscience, and empire, MS under preparation

Smith A (1776) An enquiry into the nature and causes of the wealth of nations. Modern Library, New York, 1994 Edwin Cannan (ed.)

Stone D (2000) Imperialism and sovereignty: The League of Nations' drive to control the global arms trade. J Contemp Hist 35(2):213-230

Sweeney K (2013) Firearms, militias, and the Second Amendment, 310-82. In: Saul Cornell, Kozuskanich Nathan (eds) The Second Amendment on trial: Critical essays on District of Columbia v. Heller. University of Massachusetts Press, Amherst and Boston
Sweeney K and Cornell S (2013, January 28) All guns are not created equal. Chronicle of Higher Education. www.chronicle.com/article/All-Guns-AreNot-Created-Equal/136805

\section{Additional information}

Competing interests: The authors declare no competing interests.

Reprints and permission information is available online at http://www.nature.com/ reprints

Publisher's note: Springer Nature remains neutral with regard to jurisdictional claims in published maps and institutional affiliations.

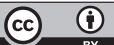

Open Access This article is licensed under a Creative Commons Attribution 4.0 International License, which permits use, sharing, adaptation, distribution and reproduction in any medium or format, as long as you give appropriate credit to the original author(s) and the source, provide a link to the Creative Commons license, and indicate if changes were made. The images or other third party material in this article are included in the article's Creative Commons license, unles indicated otherwise in a credit line to the material. If material is not included in the article's Creative Commons license and your intended use is not permitted by statutory regulation or exceeds the permitted use, you will need to obtain permission directly from the copyright holder. To view a copy of this license, visit http://creativecommons.org/ licenses/by/4.0/.

(C) The Author(s) 2019 